\title{
Is the association between vitamin $D$ and metabolic syndrome independent of other micronutrients?
}

\author{
Hossein Khosravi-Boroujeni ${ }^{1}$,Faruk Ahmed ${ }^{1} \&$ Nizal Sarrafzadegan ${ }^{2}$ \\ ${ }^{1}$ Population and Social Health Research Program, Menzies Health Institute Queensland and \\ Public Health, School of Medicine, Griffith University, Gold Coast Campus, QLD, Australia \\ ${ }^{2}$ Isfahan Cardiovascular Research Center, Cardiovascular Research Institute, Isfahan \\ University of Medical Sciences, Isfahan, Iran
}

Running title: vitamin D and metabolic syndrome

\author{
Correspondent author: Hossein Khosravi-Boroujeni \\ Public Health, School of Medicine, \\ Population and Social Health Research Program, and \\ Menzies Health Institute Queensland, \\ Griffith University, Gold Coast Campus, QLD, Australia \\ Tel: +61 755527820 \\ Fax: +61 755527899 \\ E-mail : khosravi_bh@yahoo.com
}

Running title: vitamin D and metabolic syndrome

Key words: Metabolic syndrome, Vitamin D, Vitamin A, Zinc, and Magnesium 


\begin{abstract}
:
The incidence of metabolic syndrome (MetS) has been increasing globally and it is recognized as a major public health problem. Recently, MetS has been linked to vitamin D deficiency; however, the evidence on this association remains inconclusive. This review therefore aims to depict the existing evidence related to MetS and vitamin D deficiency, and examined some of the possible confounders which may affect the association between vitamin D status and risk of MetS.

Earlier studies on the association between vitamin D deficiency and MetS adjusted the effect of some confounders including, age, sex, body mass index, race, physical activity, smoking, alcohol consumption and energy intake. However, these studies failed to consider other potential confounders. There is evidence that vitamin $\mathrm{A}$, zinc $(\mathrm{Zn})$, and magnesium $(\mathrm{Mg})$ play important roles in the activation and function of vitamin D and perform some gene expression. Furthermore, these micronutrients are also related to several components of MetS including glucose intolerance, dyslipidemia and obesity. Thus there could be an interaction between these micronutrients, vitamin $\mathrm{D}$ and MetS.

In conclusion, this review highlights the possible interactions of vitamin $\mathrm{A}, \mathrm{Zn}, \mathrm{Mg}$ and vitamin D with MetS and its components. These findings reinforce the need for further well designed studies that take into account all of the potential confounders including other micronutrients like vitamin $\mathrm{A}, \mathrm{Zn}$ and $\mathrm{Mg}$ status to investigate the independent association of vitamin D status with MetS and its components and also to look for possible interactions among other nutrients which may have similar confounding effects.
\end{abstract}

\title{
Introduction
}


Metabolic syndrome (MetS) is defined as a cluster of biochemical and physiological abnormalities and it is associated with increased risk of developing non-communicable diseases [1]. Despite the significant global effort to control the MetS risk factors, its prevalence has been increasing persistently [2] and it has now been recognized as one of the major public health problems globally [3; 4].

Although the exact causes of MetS have not yet clearly elucidated, several risk factors and unhealthy behaviours, including diet and lifestyle changes have been attributed to this condition. In recent years, the occurrence of MetS has been linked to vitamin D deficiency [5; 6]. However, the present literature on the association between vitamin D deficiency and the incidence of MetS or its components remain inconclusive [7]. For example, some studies have reported inverse association between serum vitamin D level and risk of MetS [5; 6; 8; 9]; while others have failed to demonstrate such association [10-12]. Similarly, the available literature on the findings of the association between serum vitamin D concentration and MetS components are also mixed. Some, but not all, studies reported a significant association between vitamin D deficiency and glucose intolerance [13], lipid profiles including total cholesterol, LDL, HDL and triglyceride [14], blood pressure [15] and obesity [16].

Further, a systematic review and meta-analysis has shown a negative association between blood 25-(OH) vitamin D concentrations and the risk of MetS only in cross-sectional studies but not in longitudinal studies [17]. Although some of the studies examining the association between vitamin D status and MetS have taken into account some potential confounders, the role of other components that were not assessed, is undeniably likely. Among the nutrients, some vitamins or minerals such as vitamin A, Zinc ( $\mathrm{Zn})$ and Magnesium (Mg) have a role in vitamin $\mathrm{D}$ activation and/or function. They also take part in controlling some of the MetS components including, central obesity, glucose intolerance, dyslipidemia and hypertension and altogether the development of MetS. Thus it is reasonable to expect a possible interaction of these micronutrients in the association between vitamin D and MetS. Although other micronutrients may also have similar interaction effect on the association between vitamin D and MetS, unfortunately there is no data in the current literature.

In order to fulfil this gap, the present review aims to briefly describe the current knowledge of the MetS and vitamin D including the extent of the problem, and subsequently examined some of the possible confounders which may influence the association between vitamin D status and risk of MetS.

\section{Literature search}


This review used a number online search engine including, PubMed (MEDLINE), Cochrane Library (Central) and Web of Science to identify the relevant human studies published up to June 2015. First, the literature search was conducted to identify any studies that reported the association between MetS and vitamin D. Second, in order to identify possible confounders among nutrients, the search focused on the literature that investigated the association or interaction between MetS and vitamin D and possible confounders including vitamin $\mathrm{A}, \mathrm{Zn}$, $\mathrm{Mg}$, iodine, vitamin $\mathrm{K}$, vitamin $\mathrm{C}$, vitamin $\mathrm{E}$, and calcium. A possible interaction was only reported for vitamin $\mathrm{A}, \mathrm{Zn}, \mathrm{Mg}$ and calcium in previous studies. However calcium has been already assessed as a confounder in the association between MetS and vitamin D. Thus the combination of vitamin D and vitamin A, Zinc or Magnesium were used for the database search. Titles and abstracts were individually reviewed to include relevant articles. Reference lists of selected articles were also searched for other possible related articles. Altogether, only eight human studies published in peer reviewed journals were eligible for the analysis (Table 2).

\section{Metabolic syndrome}

The MetS has received much attention in the past decades as it helps to identify the risk of both type-2 diabetes and cardiovascular diseases (CVD) [18; 19]. MetS increases the risk of diabetes mellitus, stroke, coronary heart disease, myocardial infarction and other chronic diseases [20-23]. These diseases are the leading cause of all deaths in both the developed and developing countries [24]. It has also been reported that CVD death and all-cause mortality were higher in MetS participants, even if they were free of diabetes and CVD at baseline [24]. As a consequence of sedentary lifestyles, the population ageing and the increasing prevalence of obesity, the prevalence of MetS has been increasing worldwide [25]. Globally, the reported prevalence of MetS varies between $10 \%$ to more than $80 \%$ in different populations based on different definitions [26].

Because of the importance of identifying the individuals with MetS, various expert groups/panels have attempted to define diagnostic criteria for MetS. Table 1 shows different definitions of MetS proposed by different expert groups. The first definition of MetS proposed by the World Health Organization (WHO) consultation group which was based on the importance of insulin resistance in diagnosing the MetS [27]. Then the European Group for the Study of Insulin Resistance (EGIR) suggested a modification of WHO definition 
which incorporated fasting plasma glucose as an easier method for glucose intolerance [28]. The National Cholesterol Education Program, Third Adult Treatment Panel (NCEP ATP III) definition did not obligatorily required to measure glucose intolerance, rather suggested the presence of any three of the five components: central obesity, raised blood pressure, high triglycerides, low HDL-cholesterol and fasting hyperglycaemia [29]. Finally the International Diabetes Federation (IDF) proposed that central obesity as the most important component of MetS, and thus recommended that the presence of central obesity along with any two of the four additional factors (raised blood pressure, high triglycerides, low HDL-cholesterol and fasting hyperglycaemia) was required to define the MetS [30].

\section{Risk factors of metabolic syndrome}

A wide variety of risk factors has been associated with the increased incidence of MetS. Overweight and obesity [31], ageing [32], smoking [33], physical inactivity [34], excess caloric intake [35] and genetics [36] were reported to be the most important risk factors. Other studies reported an association between MetS or its components and dietary factors, including consumption of fat [37], dairy products [38], grains [39], simple sugars [40], salt and alcohol consumption [35]. Furthermore, some minerals and vitamins were also found to be associated with the incidence of MetS. For example, studies have shown an association of MetS or it components with vitamin D [9; 41; 42], calcium [43], vitamin A [44], Zn [45] and magnesium $(\mathrm{Mg})$ [46]. Among these micronutrients, vitamin $\mathrm{D}$ is one of the most noticeable nutrients that has recently received much attention worldwide.

\section{Vitamin D}

Vitamin D deficiency or insufficiency is a widespread problem in different populations [4749] and it has been estimated that up to a billion people may be affected globally [50] and thus emphasised as a probable global pandemic in the 21st century [51]. Vitamin D can be synthesised in the skin through exposure to ultraviolet (UV) light from sun (which is a major source of vitamin D) or can be obtained through dietary intake which exerts minor influence to vitamin D status. This form of vitamin $\mathrm{D}$ is not biologically active and need to be converted to the active form in the body. First, vitamin D is converted to 25 -hydroxy vitamin $\mathrm{D}[25(\mathrm{OH}) \mathrm{D}]$ in the liver by , and then in the kidney it is converted to 1,25-dihydroxy vitamin $\mathrm{D}\left[1,25(\mathrm{OH})_{2} \mathrm{D}\right]$ which is the active form of vitamin $\mathrm{D}$ [52]. Other studies also confirmed that 
other tissues such as skin, lymph nodes, pancreas and colon also have 1-alpha-hydroxylase enzyme and can produce $\left[1,25(\mathrm{OH})_{2} \mathrm{D}\right]$ [53]. Because $1,25(\mathrm{OH})_{2} \mathrm{D}$ is formed in some tissues and it has a short half-life and it is affected by the parathyroid hormone, calcium and phosphate concentrations, serum 1,25-dihydroxy vitamin D level is not a good indicator of vitamin D status [54]. To date, serum $25(\mathrm{OH}) \mathrm{D}$ is considered to be the best measure of body vitamin D status [55]. Although there is no consensus on vitamin D sufficiency levels, vitamin D deficiency has been defined by most experts as serum $25(\mathrm{OH})$ vitamin D level lower than $50 \mathrm{nmol} / \mathrm{l}(20 \mathrm{ng} / \mathrm{ml})(20 \mathrm{ng} / \mathrm{ml})$ [56-58]. However, some other studies proposed a cut-off point of below $80 \mathrm{nmol} / \mathrm{l}(32 \mathrm{ng} / \mathrm{ml})$ to describe vitamin D insufficiency [59].

As vitamin D synthesis in the skin is the most important source of this vitamin, any factor that reduce the exposure of sunlight or decrease the concentrations of 7-dehydrocholesterol will cause vitamin D deficiency. Older individuals who have lower 7-dehydrocholesterol levels [60] and lower ability to synthesize vitamin D in the skin [61], are more susceptible to vitamin D deficiency. Consequently, in western countries, $40-100 \%$ of elderly people are vitamin D deficient $[62 ; 63]$. High prevalence of vitamin D deficiency is also observed among obese individuals, may be because of trapped vitamin $D$ in subcutaneous fat $[64 ; 65]$ or lower sunlight exposure and outdoor activity [63;66]. Urbanisation and westernized lifestyles including, indoor lifestyles, sun prevention strategies and clothing style, as well as skin pigmentation inhibit vitamin D production in the skin [67].

\section{Vitamin D functions}

The best known classical role of vitamin D is related to calcium metabolism and maintaining bone health [50]. For this function, vitamin D interrelates with its nuclear receptor in the related tissues including bone, intestine and kidney [68-70]. The non-genomic function of vitamin $\mathrm{D}$, which have been described in many cell types, include changes in the concentrations of intracellular calcium [71]. It has been shown that even in individuals with genetic defects of vitamin D metabolism, vitamin D is essential for active calcium absorption. Alternatively bone mineralization can take place by high doses of calcium [72]. In addition, vitamin $\mathrm{D}$ produces biological reactions in more than 30 target tissues and can generate genomic biological responses and regulates more than 200 genes, including those related to insulin, renin and cytokines [73]. In addition, the 1-alpha-hydroxylase enzyme [74] and $1,25(\mathrm{OH})_{2} \mathrm{D}$ nuclear receptors, known as vitamin D receptors (VDR), have been found in a 
large number of different cells and organs including skin, osteoblasts, brain, gonads, immune cells, vascular endothelial cells, pancreas, and lymphocytes [75-77].

Vitamin D performs its hormone-like functions to adjust its target genes via binding to VDR [78]. The vitamin D function is mediated through a single receptor which acts by vitamin Dresponsive elements (VDREs) which are repeated sequences of nucleotides. The 3' arm of these sequences bind the VDR and the 5' arm binds the retinoic acid X receptor (RXR) [79]. VDR, in cooperation with RXR, forms a heterodimer at the VDREs [80]. Simultaneously, VDR binds other proteins and an activator required for the gene transcription [81] which is related to several functions. Moreover, different genes are selective for the co-regulator (inhibitory or stimulatory) which with VDR heterodimer regulates their transcription [82].

It has previously been reported that individuals living at higher latitudes, and having lowest exposure to sunlight, are at a higher risk of various chronic diseases [83]. Recent studies have indicated that the risk of all-cause and cardiovascular related mortality are higher in individuals with low serum vitamin D levels [10; 84]. Low vitamin D status is also associated with diabetes, hypertension, atherosclerosis, congestive heart failure, myocardial infarction, cardiovascular risk, stroke, kidney dysfunction, infections and cancers $[8 ; 50 ; 55 ; 85-96]$. However, most recently, Theodoratou et al [97] have carried out an umbrella review of the evidence across systematic reviews and meta-analyses of observational studies and randomised controlled trials that were related to vitamin $\mathrm{D}$ and various diseases and failed to draw a firm conclusion about the beneficial effects of vitamin D and health outcomes [97].

\section{Vitamin D and Metabolic Syndrome}

Several epidemiologic studies have reported an inverse association between MetS and serum 25 hydroxy vitamin D concentrations [9; 41; 42]. In addition, other studies have shown that individuals with vitamin $\mathrm{D}$ deficiency were up to three times more at risk of developing MetS than individuals with normal vitamin D status [92; 98]. As MetS is defined by its components, any association between vitamin D deficiency and MetS components can influence the association between vitamin D and MetS. As indicated earlier, studies have found an inverse association between vitamin D status and diabetes [8; 99]. It has been suggested that vitamin D, via its effect on intracellular calcium [100], is associated with inflammation, pancreatic beta cell function and insulin resistance [101]. Moreover, adipose tissues and skeletal muscles, which are related to peripheral insulin sensitivity, have VDR [102; 103]. Pancreatic $\beta$-cells and the insulin gene promoter also have a VDR section [104], 
which could explain the role of vitamin D on glucose homeostasis. Adequate vitamin D status has also been found to be associated with blood pressure, probably by its role on the downregulation of renin and angiotensin and therefore, reducing blood pressure [105]. 1,25(OH $)_{2} \mathrm{D}$ also supress the production of renin-angiotensin system components in pancreatic islets [106]. Furthermore, the presence of VDR in vascular smooth muscles and endothelial cells may justify the vascular effect of vitamin D [107]. Vitamin D deficiency was also found to be associated with obesity [86]. It has been proposed that vitamin D may work with calcium to increase postprandial fat oxidation [108] or may inhibit adipogenesis because of its role on gene expression [109]. It has also been proposed that obese individuals need more vitamin D for stronger bones to support their greater weight, or may have lower vitamin D production as a consequence of clothing habits or restricted outdoor activity and less exposure to UVB [110].

Although several investigations accepted vitamin D deficiency as a risk factor for MetS [42; 92; 98; 111-118], several studies could not demonstrate any significant association [9-12; 42; $115 ; 119 ; 120]$.The discrepancy between studies on the association between vitamin $\mathrm{D}$ and MetS or its components has been justified by population differences in exposure to UVB irradiation, residential place, skin exposure to sunlight, different dietary intake and genetics differences [119]. Although some of these studies controlled possible confounders including, age, sex, BMI, race, physical activity, smoking, alcohol consumption, and energy intake, the role of other confounders are irrefutable. For example, vitamin $\mathrm{A}, \mathrm{Zn}, \mathrm{Mg}$, iodine, vitamin $\mathrm{K}$, vitamin $\mathrm{C}$, vitamin $\mathrm{E}$, and calcium are related to vitamin $\mathrm{D}$, MetS or its components. Based on the current literature, vitamin $\mathrm{A}, \mathrm{Zn}$, and $\mathrm{Mg}$ are related to the activation and function of vitamin $\mathrm{D}$ as well as MetS and/or its components but these micronutrients were not considered as possible confounders in previous studies. Therefore, it is likely that these micronutrients could act as potential confounders while examining the association between vitamin $\mathrm{D}$ and MetS and/or its components. Table 2 summarizes the human studies investigating the interaction between vitamin $\mathrm{D}$ and other nutrients. The following section will describe the findings of available literature which examined the possible links between these micronutrients and vitamin D and MetS.

\section{Possible role of vitamin A}

Vitamin A deficiency is a major public health problem in low income countries [121]. The main cause of vitamin A deficiency is inadequate dietary intake of vitamin A over a long 
period which leads to inefficient body stores and thus unable to meet the physiological needs [122]. Retinol, retinoic acid (RA), or pro-vitamin A ( $\beta$-carotene and other carotenoids) are the sources of vitamin $\mathrm{A}$ in the diet [123].

It has been reported that the plasma levels of vitamin A were inversely associated with MetS prevalence [124]. It has also been shown that plasma carotenoids concentrations were significantly lower in MetS participants when compared with healthy individuals and the serum carotenoids levels were significantly reduced with an increased number of MetS components [125-127]. Antioxidant activity of carotenoids that protect against oxidative stress has been suggested as a possible mechanism to reduce MetS [125]. In addition, vitamin A intake was found to be inversely associated with several biochemical and anthropometric measurements (body weight, BMI, waist circumference and waist hip ratios) that were linked to MetS manifestations [44].

Vitamin A along with vitamin D stimulates production of proteins through some gene expression [128]. Binding of RA to nuclear RA receptors (RARs) and retinoid X receptors (RXRs) forms heterodimers which regulate the expression of specific target genes [128]. This complex also supports VDR signalling and prevents the degradation of vitamin D [129]. To regulate the gene expression and transcription, RXR requires to form a heterodimer complex with VDR (VDR:RXR heterodimer) [130] (Figure 1). Synergistic or antagonistic interactions between vitamin $\mathrm{A}$ and vitamin $\mathrm{D}$ have been reported in in-vitro studies [131]. It has also reported that higher vitamin A intakes cause more prevalent and severe osteoporosis [132]. A high dose of retinol as an antagonist of vitamin D could cause osteoporosis, rickets and nonbony vitamin D related diseases [133]. In human studies, it has been demonstrated that retinol antagonizes the serum calcium response to vitamin D [134]. The interaction between vitamin A and vitamin D has confirmed by other studies [135; 136].

Thus vitamin A may act as a potential confounder while examining the association between vitamin D and MetS and hence it is important to take its effect into account in order to investigate an independent association of vitamin D and MetS.

\section{Possible role of Zinc}

Zinc ( $\mathrm{Zn}$ ) deficiency is one of the major mineral deficiencies throughout the world [123]. The Food and Agriculture Organization (FAO) reported that around 50 percent of the world's population are at a risk of inadequate intake of $\mathrm{Zn}$ [137]. The catalytic role of $\mathrm{Zn}$ has been discovered in many enzymes and around $300 \mathrm{Zn}$ metalloenzymes have been found [138]. 
Zn plays an essential role in antioxidant system including, glutathione peroxidase, superoxide dismutase, and catalase [139] and decrease production of inflammatory cytokine through Znfinger protein regulation [140]. Thus $\mathrm{Zn}$ could be related in the pathophysiology of the MetS [141]. The association between $\mathrm{Zn}$ and MetS components is contradictive. There are studies which reported that surplus $\mathrm{Zn}$, via the renin-angiotensin system, might increase blood pressure [142], and $\mathrm{Zn}$ supplementation reduces plasma HDL-C concentrations [143]. However, others recommended $\mathrm{Zn}$ supplementation as a safe intervention to decrease the risk of MetS [144]. Moreover, $\mathrm{Zn}$ affects the body fat deposition and the insulin activity [145]. It has also been connected with pancreatic $\beta$-cells insulin secretion, and so is associated with diabetes and obesity [146]. Zn deficiency and its metabolic disorders are also associated with the pathogenesis of several chronic diseases [147].

$\mathrm{Zn}$ is a vital component of steroid hormone receptors and is bound with the DNA binding domains by zinc-finger proteins. Removal of $\mathrm{Zn}$ from zinc-finger proteins changes the structure, and cause dysfunction and probably degradation of the proteins [123]. Intracellular Zn binds with VDR and influences the activity of vitamin D dependent genes [148]. Zn also improves the effect of vitamin D on the activity of alkaline phosphatase and DNA synthesis [149]. Zn deficiency causes bone calcification disorders which is comparable with vitamin $\mathrm{D}$ deficiency [150]. It has also been described that $\mathrm{Zn}$ enhances the activity of vitamin $\mathrm{D}$ dependent promoters [151]. In human studies, Zn supplementation particularly in the presence of vitamin D increase bone mass [152].

Overall, $\mathrm{Zn}$ appears to help in various functions of vitamin $\mathrm{D}$ in the body, and may also be related to some components of MetS. Thus, $\mathrm{Zn}$ status in individuals could be very important factor when examining the association between vitamin D status and the risk of MetS.

\section{Possible role of Magnesium}

$\mathrm{Mg}$ deficiency has been frequently reported in patients with hypertension [46], dyslipidemia [153], diabetes [154] and cardiovascular diseases [155]. Mg plays important roles in a wide range of biologic reactions and is responsible for more than 300 essential metabolic responses [156; 157]. Mg is connected with calcium homeostasis [158] and is also associated with the metabolism of vitamin D [159]. It is essential for the binding of vitamin D with its carrier protein thus helps in the transportation of vitamin D in the body and is necessary for the conversion of inactive vitamin $\mathrm{D}$ into active forms $\left[25(\mathrm{OH}) \mathrm{D}\right.$ and $\left.1,25(\mathrm{OH})_{2} \mathrm{D}\right]$ in the liver and kidney respectively $[160 ; 161]$. Earlier investigations found a higher prevalence of $\mathrm{Mg}$ 
insufficiency or deficiency in individuals with lower concentration of serum vitamin D [162]. Other studies revealed that $\mathrm{Mg}$ deficiency is associated with reduction in the active form of vitamin $\mathrm{D}\left[1,25(\mathrm{OH})_{2} \mathrm{D}\right]$ and causes resistance to pharmacological doses of vitamin D [159] and is related to vitamin D resistant rickets [161]. Conversely, $\mathrm{Mg}$ supplementation reduces the resistance to vitamin D treatment for rickets [160]. Additionally, a positive association between vitamin $\mathrm{D}$ levels and serum $\mathrm{Mg}$ has been reported in human studies [163-165]. Vitamin D supplementation was also associated with increased serum $\mathrm{Mg}$ concentration in obese individuals [166].

On the other hand, Mg deficiency and/or low Mg intakes are associated with MetS [167] and its components including insulin resistance [168], diabetes mellitus [169], hypertension [46], dyslipidemia [153] and cardiovascular diseases [155]. It has been suggested that Mg intake and intracellular Mg influence insulin secretion [170; 171] and insulin function [172] through its effect on calcium homeostasis, stimulation and transcription of some enzymes and nuclear proteins and oxidative stress [46]. $\mathrm{Mg}$ as a calcium antagonist, can inhibit the intracellular calcium mobilization [173], increase sodium excretion in urine and control blood pressure [173]. Mg also acts as a co-factor for several enzymes affecting lipid metabolism [174] and can decrease the absorption of fatty acids and cholesterol in intestine by forming an unabsorbable soap and decrease energy intake which may prevent obesity [175].

A recent study also showed a possible interaction between serum vitamin $\mathrm{D}, \mathrm{Mg}$ intake and mortality [165]. Because of the association between Mg deficiency and MetS, and the effect of $\mathrm{Mg}$ on the serum level of vitamin $\mathrm{D}$ and its activation, a potential interaction between vitamin $\mathrm{D}, \mathrm{Mg}$ and MetS is conceivable.

\section{Strength and limitations}

While this review revealed a complex interaction between vitamin D, MetS and other micronutrients, the major limitation is that there are limited literatures that have reported this interaction. However, the strength of this study is that it is the first review that collated the available documents to address the interaction of other micronutrients with vitamin $\mathrm{D}$ and MetS.

\section{Conclusion}


Despite the increasing evidence on the importance of vitamin $\mathrm{D}$ in the prevention of metabolic diseases, presently there is significant inconsistency in the findings of the available literature regarding the association between vitamin D status and MetS, which made it difficult to draw a firm conclusion. This review also highlights possible interactions of vitamin $\mathrm{A}, \mathrm{Zn}, \mathrm{Mg}$ and vitamin $\mathrm{D}$ with MetS and its components. Finally, this review reinforces the need for further studies by controlling the confounding effects of other nutrients to confirm the association between vitamin D status and MetS and its components and also to look for possible interactions among other nutrients which may have similar confounding effects.

\section{Conflict of interest}

The authors declare no conflict of interest.

\section{Authors' contributions}

H.K. searched and designed the concept of study and prepared the draft manuscript. F.A. and N.S. has provided guidance on the study design and critically reviewed the manuscript. All authors read and approved the final manuscript.

\section{References:}

1. Meigs, J. B., Wilson, P. W., Fox, C. S., Vasan, R. S., Nathan, D. M., Sullivan, L. M.,D'agostino, R. B. (2006) Body mass index, metabolic syndrome, and risk of type 2 diabetes or cardiovascular disease. J Clin Endocrinol Metab 91, 2906-2912 
2. Mozumdar, A.,Liguori, G. (2011) Persistent increase of prevalence of metabolic syndrome among US adults: NHANES III to NHANES 1999-2006. Diabetes care 34, 216 219

3. Zimmet, P., Magliano, D., Matsuzawa, Y., Alberti, G.,Shaw, J. (2005) The metabolic syndrome: a global public health problem and a new definition. J Atheroscler Thromb 12, 295-300

4. Sarrafzadegan, N., Kelishadi, R., Baghaei, A., Sadri, G. H., Malekafzali, H., Mohammadifard, N., Rabiei, K., Bahonar, A., Sadeghi, M.,O'laughlin, J. (2008) Metabolic syndrome: an emerging public health problem in Iranian women: Isfahan Healthy Heart Program. Int J Cardiol 131, 90-96

5. Parker, J., Hashmi, O., Dutton, D., Mavrodaris, A., Stranges, S., Kandala, N.-B., Clarke, A.,Franco, O. H. (2010) Levels of vitamin D and cardiometabolic disorders: systematic review and meta-analysis. Maturitas 65, 225-236

6. Maki, K. C., Rubin, M. R., Wong, L. G., Mcmanus, J. F., Jensen, C. D., Marshall, J. W.,Lawless, A. (2009) Serum 25-hydroxyvitamin D is independently associated with highdensity lipoprotein cholesterol and the metabolic syndrome in men and women. J Clin Lipidol 3, 289-296

7. L Gulseth, H., Mf Gjelstad, I., I Birkeland, K.,A Drevon, C. (2013) Vitamin D and the metabolic syndrome. Curr Vasc Pharmacol 11, 968-984

8. Scragg, R., Sowers, M.,Bell, C. (2004) Serum 25-hydroxyvitamin D, diabetes, and ethnicity in the Third National Health and Nutrition Examination Survey. Diabetes care 27, 2813-2818

9. Hyppönen, E., Boucher, B. J., Berry, D. J.,Power, C. (2008) 25-hydroxyvitamin D, IGF-1, and metabolic syndrome at 45 years of age A cross-sectional study in the 1958 British Birth Cohort. Diabetes 57, 298-305

10. Melamed, M. L., Michos, E. D., Post, W.,Astor, B. (2008) 25-hydroxyvitamin D levels and the risk of mortality in the general population. Arch Intern Med 168, 1629-1637

11. Bonakdaran, S.,Varasteh, A.-R. (2009) Correlation between serum 25 hydroxy vitamin D3 and laboratory risk markers of cardiovascular diseases in type 2 diabetic patients. Saudi Med J 30, 509-514

12. Rueda, S., Fernández-Fernández, C., Romero, F., De Osaba, M. J. M., Vidal, J. (2008) Vitamin D, PTH, and the metabolic syndrome in severely obese subjects. Obes Surg 18, 151 154

13. Gagnon, C., Lu, Z. X., Magliano, D. J., Dunstan, D. W., Shaw, J. E., Zimmet, P. Z., Sikaris, K., Ebeling, P. R.,Daly, R. M. (2012) Low serum 25-hydroxyvitamin D is associated with increased risk of the development of the metabolic syndrome at five years: results from a national, population-based prospective study (The Australian Diabetes, Obesity and Lifestyle Study: AusDiab). J Clin Endocrinol Metab 97, 1953-1961

14. Ponda, M. P., Huang, X., Odeh, M. A., Breslow, J. L.,Kaufman, H. W. (2012)

Vitamin D May Not Improve Lipid LevelsClinical Perspective A Serial Clinical Laboratory Data Study. Circulation 126, 270-277

15. Vimaleswaran, K. S., Cavadino, A., Berry, D. J., Jorde, R., Dieffenbach, A. K., Lu, C., Alves, A. C., Heerspink, H. J. L., Tikkanen, E.,Eriksson, J. (2014) Association of vitamin D status with arterial blood pressure and hypertension risk: a mendelian randomisation study. Lancet Diabetes Endocrinol 2, 719-729

16. González, L., Ramos-Trautmann, G., Díaz-Luquis, G. M., Pérez, C. M.,Palacios, C. (2015) Vitamin D status is inversely associated with obesity in a clinic-based sample in Puerto Rico. Nutr Res 35, 287-293 
17. Ju, S. Y., Jeong, H. S.,Kim, D. H. (2013) Blood Vitamin D Status and Metabolic Syndrome in the General Adult Population: A Dose-Response Meta-Analysis. J Clin Endocrinol Metab 99, 1053-1063

18. Cameron, A. J., Shaw, J. E.,Zimmet, P. Z. (2004) The metabolic syndrome: prevalence in worldwide populations. Endocrinol Metab Clin North Am 33, 351-375 19. Talaei, M., Sadeghi, M., Marshall, T., Thomas, G., Kabiri, P., Hoseini, S.,Sarrafzadegan, N. (2012) Impact of metabolic syndrome on ischemic heart disease-A prospective cohort study in an Iranian adult population: Isfahan cohort study. Nutr Metab Cardiovasc Dis 22, 434-441

20. Mcneill, A., Rosamond, W., Girman, C., Golden, S., Schmidt, M., East, H., Ballantyne, C.,Heiss, G. (2005) The metabolic syndrome and 11-year risk of incident cardiovascular disease in the atherosclerosis risk in communities study. Diabetes Care 28, 385-390

21. Resnick, H., Jones, K., Ruotolo, G., Jain, A., Henderson, J., Lu, W.,Howard, B. (2003) Insulin resistance, the metabolic syndrome, and risk of incident cardiovascular disease in nondiabetic American Indians. Diabetes Care 26, 861-867

22. Pyorala, M., Miettinen, H., Halonen, P., Laakso, M.,Pyorala, K. (2000) Insulin resistance syndrome predicts the risk of coronary heart disease and stroke in healthy middleaged men the 22-year follow-up results of the Helsinki Policemen Study. Arterioscler Thromb Vasc Biol 20, 538-544

23. Lakka, H., Laaksonen, D., Lakka, T., Niskanen, L., Kumpusalo, E., Tuomilehto, J.,Salonen, J. (2002) The metabolic syndrome and total and cardiovascular disease mortality in middle-aged men. Jama 288, 2709-2716

24. Lakka, H., Laaksonen, D., Lakka, T., Niskanen, L., Kumpusalo, E., Tuomilehto, J.,Salonen, J. (2002) The metabolic syndrome and total and cardiovascular disease mortality in middle-aged men. JAMA: the journal of the American Medical Association 288, 2709 2716

25. Eckel, R. H., Grundy, S. M.,Zimmet, P. Z. (2005) The metabolic syndrome. Lancet $365,1415-1428$

26. Kaur, J. (2013) A Comprehensive Review on Metabolic Syndrome. Cardiol Res Pract 2014, 943162-943183

27. World Health Organization (1999) Definition, diagnosis and classification of diabetes mellitus and its complications. Report of a WHO consultation, Geneva: World Health Organization

28. Balkau, B.,Charles, M.-A. (1999) Comment on the provisional report from the WHO consultation. Diabet Med 16, 442-443

29. Expert Panel on Detection, E., And Treatment of High Blood Cholesterol in Adults (2001) Executive summary of the third report of the National Cholesterol Education Program (NCEP) expert panel on Detection, Evaluation, and Treatment of high blood cholesterol in adults (Adult Treatment Panel III). JAMA: the journal of the American Medical Association 285, 2486-2497

30. Alberti, K., Zimmet, P.,Shaw, J. (2006) Metabolic syndrome-a new world-wide definition. A consensus statement from the international diabetes federation. Diabet Med 23, 469-480

31. Kelliny, C., William, J., Riesen, W., Paccaud, F.,Bovet, P. (2008) Metabolic syndrome according to different definitions in a rapidly developing country of the African region. Cardiovascular diabetology 7, 1-11

32. Grundy, S. M., Brewer, H. B., Cleeman, J. I., Smith, S. C.,Lenfant, C. (2004)

Definition of metabolic syndrome report of the National Heart, Lung, and Blood 
Institute/American Heart Association Conference on scientific issues related to definition. Circulation 109, 433-438

33. Reaven, G. (2002) Metabolic syndrome pathophysiology and implications for management of cardiovascular disease. Circulation 106, 286-288

34. Grundy, S. M., Cleeman, J. I., Daniels, S. R., Donato, K. A., Eckel, R. H., Franklin, B. A., Gordon, D. J., Krauss, R. M., Savage, P. J.,Smith, S. C. (2005) Diagnosis and management of the metabolic syndrome an American Heart Association/National Heart, Lung, and Blood Institute scientific statement. Circulation 112, 2735-2752

35. Djousse, L., Padilla, H., Nelson, T., Gaziano, J.,Mukamal, K. (2010) Diet and metabolic syndrome. Endocr Metab Immune Disord Drug Targets 10, 124-137

36. Terán-García, M.,Bouchard, C. (2007) Genetics of the metabolic syndrome. Appl Physiol Nutr Metab 32, 89-114

37. Riccardi, G., Giacco, R.,Rivellese, A. (2004) Dietary fat, insulin sensitivity and the metabolic syndrome. Clin Nutr 23, 447-456

38. Sadeghi, M., Khosravi-Boroujeni, H., Sarrafzadegan, N., Asgary, S., Roohafza, H., Gharipour, M., Sajjadi, F., Khalesi, S.,Rafieian-Kopaei, M. (2014) Cheese consumption in relation to cardiovascular risk factors among Iranian adults-IHHP Study. NRP 8, 336-341

39. Khosravi-Boroujeni, H., Sarrafzadegan, N., Mohammadifard, N., Sajjadi, F., Maghroun, M., Asgari, S., Rafieian-Kopaei, M.,Azadbakht, L. (2013) White rice consumption and CVD risk factors among Iranian population. J Health Popul Nutr 31, 252 261

40. Khosravi-Boroujeni, H., Sarrafzadegan, N., Mohammadifard, N., Alikhasi, H., Sajjadi, F., Asgari, S.,Esmaillzadeh, A. (2012) Consumption of sugar-sweetened beverages in relation to the metabolic syndrome among Iranian adults. Obes facts 5, 527-537

41. Lu, L., Yu, Z., Pan, A., Hu, F. B., Franco, O. H., Li, H., Li, X., Yang, X., Chen, Y.,Lin, X. (2009) Plasma 25-hydroxyvitamin D concentration and metabolic syndrome among middle-aged and elderly Chinese individuals. Diabetes care 32, 1278-1283

42. Ford, E. S., Ajani, U. A., Mcguire, L. C.,Liu, S. (2005) Concentrations of serum vitamin D and the metabolic syndrome among US adults. Diabetes care 28, 1228-1230 43. Liu, S., Song, Y., Ford, E. S., Manson, J. E., Buring, J. E.,Ridker, P. M. (2005) Dietary calcium, vitamin D, and the prevalence of metabolic syndrome in middle-aged and older US women. Diabetes care 28, 2926-2932

44. Zulet, M., Puchau, B., Hermsdorff, H., Navarro, C.,Martinez, J. A. (2008) Vitamin A intake is inversely related with adiposity in healthy young adults. J Nutr Sci Vitaminol 54, 347-352

45. Kechrid, Z., Hamdi, M., Nazıroğlu, M.,Flores-Arce, M. (2012) Vitamin D supplementation modulates blood and tissue zinc, liver glutathione and blood biochemical parameters in diabetic rats on a zinc-deficient diet. Biol Trace Elem Res 148, 371-377

46. Barbagallo, M., Dominguez, L. J., Galioto, A., Ferlisi, A., Cani, C., Malfa, L., Pineo, A., Busardo, A.,Paolisso, G. (2003) Role of magnesium in insulin action, diabetes and cardiometabolic syndrome X. Mol Aspects Med 24, 39-52

47. Moniz, C., Dew, T.,Dixon, T. (2005) Prevalence of vitamin D inadequacy in osteoporotic hip fracture patients in London. Curr Med Res Opin 21, 1891-1894

48. Ben-Shoshan, M. (2012) Vitamin D deficiency/insufficiency and challenges in developing global vitamin D fortification and supplementation policy in adults. Int J Vitam Nutr Res 82, 237-259

49. Koenig, J.,Elmadfa (2000) Status of Calcium and VitaminD of Different Population Groups in Austria. Int J Vitam Nutr Res 70, 214-220

50. Holick, M. F. (2007) Vitamin D deficiency. N Engl J Med 357, 266-281 
51. Plehwe, W. E. (2003) Vitamin D deficiency in the 21st century: an unnecessary pandemic? Clin endocrinol 59, 22-24

52. Holick, M., Schnoes, H.,Deluca, H. (1971) Identification of 1, 25-

dihydroxycholecalciferol, a form of vitamin D3 metabolically active in the intestine. Proc

Natl Acad Sci U S A 68, 803-804

53. Hewison, M., Zehnder, D., Bland, R.,Stewart, P. (2000) 1alpha-Hydroxylase and the action of vitamin D. J Mol Endocrinol 25, 141-148

54. Zerwekh, J. E. (2008) Blood biomarkers of vitamin D status. Am J Clin Nutr 87, 1087S-1091S

55. Wang, T. J., Pencina, M. J., Booth, S. L., Jacques, P. F., Ingelsson, E., Lanier, K., Benjamin, E. J., D’agostino, R. B., Wolf, M.,Vasan, R. S. (2008) Vitamin D deficiency and risk of cardiovascular disease. Circulation 117, 503-511

56. Zittermann, A. (2006) Vitamin D and disease prevention with special reference to cardiovascular disease. Prog Biophys Mol Biol 92, 39-48

57. Holick, M. F. (2006) High prevalence of vitamin D inadequacy and implications for health. In Mayo Clin Proc, Elsevier. pp 353-373

58. Bischoff-Ferrari, H. A., Giovannucci, E., Willett, W. C., Dietrich, T.,Dawson-Hughes, B. (2006) Estimation of optimal serum concentrations of 25-hydroxyvitamin D for multiple health outcomes. Am J Clin Nutr 84, 18-28

59. Gómez, A. C., Naves, D. M., Rodríguez, G. M., Fernández, M. J.,Cannata, A. J. (2003) Review of the concept of vitamin D" sufficiency and insufficiency"]. Nefrología: publicación oficial de la Sociedad Española Nefrologia 23, 73

60. Maclaughlin, J.,Holick, M. F. (1985) Aging decreases the capacity of human skin to produce vitamin D3. J Clin Invest 76, 1536-1538

61. Holick, M., Matsuoka, L.,Wortsman, J. (1989) Age, vitamin D, and solar ultraviolet. The Lancet 334, 1104-1105

62. Nadir, M. A., Szwejkowski, B. R.,Witham, M. D. (2010) Vitamin D and

cardiovascular prevention. Cardiovascular therapeutics 28, e5-e12

63. Michos, E. D., Reis, J. P.,Melamed, M. L. (2010) Vitamin D status and cardiovascular health: a 2009 Update. Open Clin Chem J 3, 51-59

64. Arunabh, S., Pollack, S., Yeh, J.,Aloia, J. F. (2003) Body fat content and 25-

hydroxyvitamin D levels in healthy women. J Clin Endocrinol Metab 88, 157-161

65. Wortsman, J., Matsuoka, L. Y., Chen, T. C., Lu, Z.,Holick, M. F. (2000) Decreased

bioavailability of vitamin D in obesity. Am J Clin Nutr 72, 690-693

66. Scragg, R.,Camargo, C. A. (2008) Frequency of leisure-time physical activity and serum 25-hydroxyvitamin D levels in the US population: results from the Third National Health and Nutrition Examination Survey. Am J Epidemiol 168, 577-586

67. Gannagé- Yared, M. H., Chemali, R., Yaacoub, N.,Halaby, G. (2000)

Hypovitaminosis D in a sunny country: relation to lifestyle and bone markers. J Bone Miner Res $15,1856-1862$

68. Holick, M. F. (2002) Vitamin D: the underappreciated D-lightful hormone that is important for skeletal and cellular health. Curr Opin Endocrinol Diabetes Obes 9, 87-98 69. Holick, M. F. (2009) Vitamin D status: measurement, interpretation, and clinical application. Annals of epidemiology 19, 73-78

70. Deluca, H. F.,Cantorna, M. T. (2001) Vitamin D: its role and uses in immunology. FASEB J 15, 2579-2585

71. Boland, R., De Boland, A. R., Buitrago, C., Morelli, S., Santillán, G., Vazquez, G., Capiati, D.,Baldi, C. (2002) Non-genomic stimulation of tyrosine phosphorylation cascades by $1,25(\mathrm{OH}) 2 \mathrm{D} 3$ by VDR-dependent and-independent mechanisms in muscle cells.

Steroids 67, 477-482 
72. Lips, P. (2006) Vitamin D physiology. Prog Biophys Mol Biol 92, 4-8

73. Norman, A. W., Henry, H. L., Bishop, J. E., Song, X.-D., Bula, C.,Okamura, W. H. (2001) Different shapes of the steroid hormone $1 \alpha, 25(\mathrm{OH}) 2$-vitamin $\mathrm{D}<\mathrm{sub}>3</$ sub $>$ act as agonists for two different receptors in the vitamin $\mathrm{D}$ endocrine system to mediate genomic and rapid responses 2 . Steroids 66, 147-158

74. Stöcklin, E.,Eggersdorfer, M. (2013) Vitamin D, an essential nutrient with versatile functions in nearly all organs. Int J Vitam Nutr Res 83, 92-100

75. Stumpf, W. E., Sar, M., Reid, F. A., Tanaka, Y.,Deluca, H. F. (1979) Target cells for 1, 25-dihydroxyvitamin D3 in intestinal tract, stomach, kidney, skin, pituitary, and parathyroid. Science 206, 1188-1190

76. Manolagas, S. C., Provvedini, D. M.,Tsoukas, C. D. (1985) Interactions of 1, $25-$ dihydroxyvitamin D 3 and the immune system. Mol Cell Endocrinol 43, 113-122

77. Mathieu, C.,Adorini, L. (2002) The coming of age of 1, 25-dihydroxyvitamin D 3 analogs as immunomodulatory agents. Trends Mol Med 8, 174-179

78. Haussler, M., Haussler, C., Jurutka, P., Thompson, P., Hsieh, J., Remus, L., Selznick, S.,Whitfield, G. (1997) The vitamin D hormone and its nuclear receptor: molecular actions and disease states. J Endocrinol 154, S57-S73

79. Deluca, H. F. (2004) Overview of general physiologic features and functions of vitamin D. Am J Clin Nutr 80, 1689S-1696S

80. Jones, G., Strugnell, S. A.,Deluca, H. F. (1998) Current understanding of the molecular actions of vitamin D. Physiol Rev 78, 1193-1231

81. Mcphee, S. J., Papadakis, M. A.,Rabow, M. W. (2010) Current medical diagnosis \& treatment 2010, McGraw-Hill Medical

82. Oda, Y., Sihlbom, C., Chalkley, R. J., Huang, L., Rachez, C., Chang, C.-P. B., Burlingame, A. L., Freedman, L. P.,Bikle, D. D. (2003) Two distinct coactivators, $\mathrm{DRIP} / \mathrm{mediator}$ and SRC/p160, are differentially involved in vitamin D receptor transactivation during keratinocyte differentiation. Mol Endocrinol 17, 2329-2339

83. Rostand, S. G. (1997) Ultraviolet light may contribute to geographic and racial blood pressure differences. Hypertension 30, 150-156

84. Dobnig, H., Pilz, S., Scharnagl, H., Renner, W., Seelhorst, U., Wellnitz, B., Kinkeldei, J., Boehm, B. O., Weihrauch, G.,Maerz, W. (2008) Independent association of low serum 25-hydroxyvitamin D and 1, 25-dihydroxyvitamin D levels with all-cause and cardiovascular mortality. Arch Intern Med 168, 1340-1349

85. Peterlik, M.,Cross, H. (2005) Vitamin D and calcium deficits predispose for multiple chronic diseases. Eur J Clin Invest 35, 290-304

86. Martins, D., Wolf, M., Pan, D., Zadshir, A., Tareen, N., Thadhani, R., Felsenfeld, A., Levine, B., Mehrotra, R.,Norris, K. (2007) Prevalence of cardiovascular risk factors and the serum levels of 25-hydroxyvitamin D in the United States: data from the Third National Health and Nutrition Examination Survey. Arch Intern Med 167, 1159-1165

87. Scragg, R., Sowers, M.,Bell, C. (2007) Serum 25-hydroxyvitamin D, ethnicity, and blood pressure in the Third National Health and Nutrition Examination Survey. Am J Hypertension 20, 713-719

88. De Boer, I. H., Ioannou, G. N., Kestenbaum, B., Brunzell, J. D.,Weiss, N. S. (2007) 25-hydroxyvitamin D levels and albuminuria in the Third National Health and Nutrition Examination Survey (NHANES III). Am J Kidney Dis 50, 69-77

89. Chonchol, M.,Scragg, R. (2006) 25-Hydroxyvitamin D, insulin resistance, and kidney function in the Third National Health and Nutrition Examination Survey. Kidney Int 71, 134139 
90. Kendrick, J., Targher, G., Smits, G.,Chonchol, M. (2009) 25-Hydroxyvitamin D deficiency is independently associated with cardiovascular disease in the Third National Health and Nutrition Examination Survey. Atherosclerosis 205, 255-260

91. Krause, R., Bühring, M., Hopfenmüller, W., Holick, M. F.,Sharma, A. M. (1998) Ultraviolet B and blood pressure. The Lancet 352, 709-710

92. Chiu, K. C., Chu, A., Go, V. L. W.,Saad, M. F. (2004) Hypovitaminosis D is associated with insulin resistance and $\beta$ cell dysfunction. Am J Clin Nutr 79, 820-825

93. Cigolini, M., Iagulli, M. P., Miconi, V., Galiotto, M., Lombardi, S.,Targher, G. (2006)

Serum 25-hydroxyvitamin D3 concentrations and prevalence of cardiovascular disease among type 2 diabetic patients. Diabetes care 29, 722-724

94. Targher, G., Bertolini, L., Padovani, R., Zenari, L., Scala, L., Cigolini, M.,Arcaro, G. (2006) Serum 25-hydroxyvitamin D3 concentrations and carotid artery intima-media thickness among type 2 diabetic patients. Clin endocrinol 65, 593-597

95. Zittermann, A., Schleithoff, S. S., Tenderich, G., Berthold, H. K., Körfer, R.,Stehle, P. (2003) Low vitamin D status: a contributing factor in the pathogenesis of congestive heart failure? JAmColl Cardiol 41, 105-112

96. Rodríguez-Rodríguez, E., Aparicio, A., Andrés, P.,Ortega, R. M. (2014) Moderate Vitamin D Deficiency and Inflammation Related Markers in Overweight/Obese Schoolchildren. Int J Vitam Nutr Res 84, 98-107

97. Theodoratou, E., Tzoulaki, I., Zgaga, L.,Ioannidis, J. (2014) Vitamin D and multiple health outcomes: umbrella review of systematic reviews and meta-analyses of observational studies and randomised trials. BMJ 348, 1-19

98. Botella-Carretero, J. I., Alvarez-Blasco, F., Villafruela, J. J., Balsa, J. A., Vázquez, C.,Escobar-Morreale, H. F. (2007) Vitamin D deficiency is associated with the metabolic syndrome in morbid obesity. Clin Nutr 26, 573-580

99. Holick, M. F. (2004) Vitamin D: importance in the prevention of cancers, type 1 diabetes, heart disease, and osteoporosis. Am J Clin Nutr 79, 362-371

100. Pittas, A. G., Lau, J., Hu, F. B.,Dawson-Hughes, B. (2007) The role of vitamin D and calcium in type 2 diabetes. A systematic review and meta-analysis. J Clin Endocrinol Metab 92, 2017-2029

101. Kayaniyil, S., Vieth, R., Retnakaran, R., Knight, J. A., Qi, Y., Gerstein, H. C., Perkins, B. A., Harris, S. B., Zinman, B.,Hanley, A. J. (2010) Association of vitamin D with insulin resistance and $\beta$-cell dysfunction in subjects at risk for type 2 diabetes. Diabetes care 33, 1379-1381

102. Wild, S., Roglic, G., Green, A., Sicree, R.,King, H. (2004) Global prevalence of diabetes estimates for the year 2000 and projections for 2030. Diabetes care 27, 1047-1053

103. Holt, R. I., Bushe, C.,Citrome, L. (2005) Diabetes and schizophrenia 2005: are we any closer to understanding the link? J Psychopharmacol 19, 56-65

104. Ramachandran, A., Snehalatha, C., Satyavani, K., Sivasankari, S., Vijay, V. (2003)

Metabolic syndrome in urban Asian Indian adults - a population study using modified ATP

III criteria. Diab Pract Res Clin 60, 199-204

105. Li, Y. C., Kong, J., Wei, M., Chen, Z.-F., Liu, S. Q.,Cao, L.-P. (2002) 1, 25 -

Dihydroxyvitamin D3 is a negative endocrine regulator of the renin-angiotensin system. $\mathrm{J}$ Clin Invest 110, 229-238

106. Leung, P. S.,Cheng, Q. (2010) The novel roles of glucagon-like peptide-1, angiotensin II, and vitamin D in islet function. In The Islets of Langerhans, Springer. pp 339-361

107. Florentin, M., S Elisaf, M., P Mikhailidis, D.,N Liberopoulos, E. (2010) Vitamin D and metabolic syndrome: is there a link? Curr Pharm Des 16, 3417-3434 
108. Chan She Ping-Delfos, W.,Soares, M. (2011) Diet induced thermogenesis, fat oxidation and food intake following sequential meals: influence of calcium and vitamin $\mathrm{D}$. Clin Nutr 30, 376-383

109. Kong, J.,Li, Y. C. (2006) Molecular mechanism of 1, 25-dihydroxyvitamin D3 inhibition of adipogenesis in 3T3-L1 cells. Am J Physiol Endocrinol Metab 290, E916-E924 110. Holick, M. F. (2004) Sunlight and vitamin D for bone health and prevention of autoimmune diseases, cancers, and cardiovascular disease. Am J Clin Nutr 80, 1678S-1688S 111. Boucher, B., Mannan, N., Noonan, K., Hales, C.,Evans, S. (1995) Glucose intolerance and impairment of insulin secretion in relation to vitamin D deficiency in east London Asians. Diabetologia 38, 1239-1245

112. Lind, L., Hänni, A., Lithell, H., Hvarfner, A., Sörensen, O.,Ljunghall, S. (1995) Vitamin D is related to blood pressure and other cardiovascular risk factors in middle-aged men. Am J Hypertens 8, 894-901

113. Reis, J. P., Von Mühlen, D.,Miller, E. R. (2008) Relation of 25-hydroxyvitamin D and parathyroid hormone levels with metabolic syndrome among US adults. Eur J Endocrinol 159, 41-48

114. Al-Daghri, N. M., Alkharfy, K. M., Al-Saleh, Y., Al-Attas, O. S., Alokail, M. S., AlOthman, A., Moharram, O., El-Kholie, E., Sabico, S.,Kumar, S. (2012) Modest reversal of metabolic syndrome manifestations with vitamin D status correction: a 12-month prospective study. Metabolism 61, 661-666

115. Liu, E., Meigs, J. B., Pittas, A. G., Mckeown, N. M., Economos, C. D., Booth, S. L.,Jacques, P. F. (2009) Plasma 25-hydroxyvitamin D is associated with markers of the insulin resistant phenotype in nondiabetic adults. J Nutr 139, 329-334

116. Martini, L. A.,Wood, R. J. (2006) Vitamin D status and the metabolic syndrome. Nutr Rev 64, 479-486

117. Smotkin-Tangorra, M., Purushothaman, R., Gupta, A., Nejati, G., Anhalt, H.,Ten, S. (2007) Prevalence of vitamin D insufficiency in obese children and adolescents. J Pediatr Endocrinol Metab 20, 817-824

118. Boucher, B. (1998) Inadequate vitamin D status: does it contribute to the disorders comprising syndrome'X'? Br J Nutr 79, 315-328

119. Reis, J. P., Von Mühlen, D., Kritz-Silverstein, D., Wingard, D. L.,Barrett-Connor, E. (2007) Vitamin D, parathyroid hormone levels, and the prevalence of metabolic syndrome in community-dwelling older adults. Diabetes care 30, 1549-1555

120. Tai, K., Need, A. G., Horowitz, M.,Chapman, I. M. (2008) Glucose tolerance and vitamin D: effects of treating vitamin D deficiency. Nutrition 24, 950-956

121. West Jr, K. P., Gernand, A.,Sommer, A. (2007) Vitamin A in nutritional anemia. Nutritional Anemia, 133-154

122. World Health Organization (2009) Global prevalence of vitamin A deficiency in populations at risk 1995-2005: WHO global database on vitamin A deficiency.

http://www.who.int/iris/handle/10665/44110\#sthash.YhhtWZs2.dpufAccess, 2009

123. Shils, M. E.,Shike, M. (2006) Modern nutrition in health and disease, Lippincott Williams \& Wilkins

124. Godala, M., Materek-Kuśmierkiewicz, I., Moczulski, D., Rutkowski, M., Szatko, F., Gaszyńska, E.,Kowalski, J. (2014) Estimation of plasma vitamin A, C and E levels in patients with metabolic syndrome. Pol Merkur Lekarski 36, 320

125. Suzuki, K., Ito, Y., Inoue, T.,Hamajima, N. (2011) Inverse association of serum carotenoids with prevalence of metabolic syndrome among Japanese. Clin Nutr 30, 369-375 126. Ford, E. S., Mokdad, A. H., Giles, W. H.,Brown, D. W. (2003) The metabolic syndrome and antioxidant concentrations findings from the Third National Health and Nutrition Examination Survey. Diabetes 52, 2346-2352 
127. Coyne, T., Ibiebele, T. I., Baade, P. D., Mcclintock, C. S.,Shaw, J. E. (2009)

Metabolic syndrome and serum carotenoids: findings of a cross-sectional study in Queensland, Australia. Br J Nutr 102, 1668-1677

128. Germain, P., Chambon, P., Eichele, G., Evans, R., Lazar, M., Leid, M., De Lera, A., Lotan, R., Mangelsdorf, D.,Gronemeyer, H. (2006) The pharmacology and classification of the nuclear receptor superfamily. Retinoic acid receptors (RARs). Pharmacol Rev 58, 712725

129. Sánchez Martínez, R., Castillo, A. I., Steinmeyer, A.,Aranda, A. (2006) The retinoid $\mathrm{X}$ receptor ligand restores defective signalling by the vitamin D receptor. EMBO Rep 7, 1030-1034

130. Bettoun, D. J., Burris, T. P., Houck, K. A., Buck, D. W., Stayrook, K. R., Khalifa, B., Lu, J., Chin, W. W.,Nagpal, S. (2003) Retinoid X receptor is a nonsilent major contributor to vitamin D receptor-mediated transcriptional activation. Mol Endocrinol 17, 2320-2328 131. Haussler, M. R., Whitfield, G. K., Haussler, C. A., Hsieh, J. C., Thompson, P. D., Selznick, S. H., Dominguez, C. E.,Jurutka, P. W. (1998) The nuclear vitamin D receptor: biological and molecular regulatory properties revealed. J Bone Miner Res 13, 325-349 132. Schrijver, J.,Van Den Berg, H. (2003) Nutrition and health--vitamins and vitamin supplements. Ned Tijdschr Geneeskd 147, 752-756

133. J Boucher, B. (2011) Vitamin D insufficiency and diabetes risks. Curr Drug Targets $12,61-87$

134. Johansson, S.,Melhus, H. (2001) Vitamin A antagonizes calcium response to vitamin D in man. J Bone Miner Res 16, 1899-1905

135. Schmutz, E. A., Zimmermann, M. B.,Rohrmann, S. (2015) The inverse association between serum 25 -hydroxyvitamin $\mathrm{D}$ and mortality may be modified by vitamin A status and use of vitamin A supplements. Eur J Nutr, 1-10

136. Cheng, T. Y. D., Goodman, G. E., Thornquist, M. D., Barnett, M. J., Beresford, S. A., Lacroix, A. Z., Zheng, Y.,Neuhouser, M. L. (2014) Estimated intake of vitamin D and its interaction with vitamin A on lung cancer risk among smokers. Int J Cancer 137. Brown, K. H.,Wuehler, S. E. (2000) Zinc and human health: results of recent trials and implications for program interventions and research, Micronutrient Initiative 138. Blasie, C. A.,Berg, J. M. (2002) Structure-based thermodynamic analysis of a coupled metal binding-protein folding reaction involving a zinc finger peptide. Biochemistry 41, 15068-15073

139. Mccall, K. A., Huang, C.-C.,Fierke, C. A. (2000) Function and mechanism of zinc metalloenzymes. J Nutr 130, 1437S-1446S

140. Prasad, A. S. (2009) Zinc: role in immunity, oxidative stress and chronic inflammation. Curr Opin Clin Nutr Metab Care 12, 646-652

141. Arnaud, J., De Lorgeril, M., Akbaraly, T., Salen, P., Arnout, J., Cappuccio, F. P., Van Dongen, M., Donati, M., Krogh, V.,Siani, A. (2012) Gender differences in copper, zinc and selenium status in diabetic-free metabolic syndrome European population-The IMMIDIET study. Nutr Metab Cardiovasc Dis 22, 517-524

142. Kasai, M., Miyazaki, T., Takenaka, T., Yanagisawa, H.,Suzuki, H. (2012) Excessive zinc intake increases systemic blood pressure and reduces renal blood flow via kidney angiotensin II in rats. Biol Trace Elem Res 150, 285-290

143. Hughes, S.,Samman, S. (2006) The effect of zinc supplementation in humans on plasma lipids, antioxidant status and thrombogenesis. J Am Coll Nutr 25, 285-291

144. Hashemipour, M., Kelishadi, R., Shapouri, J., Sarrafzadegan, N., Amini, M., Tavakoli, N., Movahedian-Attar, A., Mirmoghtadaee, P.,Poursafa, P. (2009) Effect of zinc supplementation on insulin resistance and components of the metabolic syndrome in prepubertal obese children. Hormones (Athens) 8, 279-285 
145. Lee, J., Lee, H. J., Lee, I. K., Yoon, J. S. (2005) Relationship between zinc status and obesity of type 2 diabetic women. Korean J Community Nutr 10, 70-78

146. Naik, H. B., Beshire, M., Walsh, B. M., Liu, J.,Soybel, D. I. (2009) Secretory state regulates $\mathrm{Zn} 2+$ transport in gastric parietal cell of the rabbit. American Journal of Physiology-Cell Physiology 297, C979-989

147. Maret, W. (2005) Zinc and diabetes. Biometals 18, 293-294

148. Craig, T. A., Benson, L. M., Naylor, S.,Kumar, R. (2001) Modulation effects of zinc on the formation of vitamin D receptor and retinoid X receptor $\alpha$ - DNA transcription complexes: analysis by microelectrospray mass spectrometry. Rapid Commun Mass Spectrom 15, 1011-1016

149. Yamaguchi, M.,Kitajima, T. (1991) Effect of estrogen on bone metabolism in tissue culture: enhancement of the steroid effect by zinc. Res Exp Med 191, 145-154

150. Xu, B., Zheng, D., Qian, Y.,Wu, K. (1992) [Effects of zinc deficiency and vitamin D deficiency on bone calcification and development of rats]. Hua xi yi ke da xue xue bao (Journal of West China University of Medical Sciences) 23, 288-292

151. Lutz, W., Burritt, M. F., Nixon, D. E., Kao, P. C.,Kumar, R. (2000) Zinc increases the activity of vitamin D-dependent promoters in osteoblasts. Biochem Biophys Res Commun $271,1-7$

152. Ekbote, V., Khadilkar, A.,Mughal, Z. (2015) Bone mineral content in growth hormone deficient children treated with growth hormone after withdrawal of supplementation with calcium, vitamin D and zinc. Endocrine 49, 298-299

153. Guerrero-Romero, F.,Rodriguez-Moran, M. (2000) Hypomagnesemia is linked to low serum HDL-cholesterol irrespective of serum glucose values. J Diabetes Complicat 14, 272276

154. De Lourdes Lima, M., Cruz, T., Pousada, J. C., Rodrigues, L. E., Barbosa, K.,Canguçu, V. (1998) The effect of magnesium supplementation in increasing doses on the control of type 2 diabetes. Diabetes care 21, 682-686

155. Abbott, R. D., Ando, F., Masaki, K. H., Tung, K.-H., Rodriguez, B. L., Petrovitch, H., Yano, K.,Curb, J. D. (2003) Dietary magnesium intake and the future risk of coronary heart disease (the Honolulu Heart Program). Am J Cardiol 92, 665-669

156. Maguire, M. E.,Cowan, J. A. (2002) Magnesium chemistry and biochemistry.

Biometals 15, 203-210

157. Wolf, F. I.,Cittadini, A. (2003) Chemistry and biochemistry of magnesium. Mol

Aspects Med 24, 3-9

158. Van Den Bergh, W., Van De Water, J., Hoff, R., Algra, A.,Rinkel, G. (2008) Calcium homeostasis during magnesium treatment in aneurysmal subarachnoid hemorrhage. Neurocrit Care 8, 413-417

159. Rude, R. K., Singer, F. R.,Gruber, H. E. (2009) Skeletal and hormonal effects of magnesium deficiency. J Am Coll Nutr 28, 131-141

160. Reddy, V.,Sivakumar, B. (1974) Magnesium-dependent vitamin-D-resistant rickets. Lancet 303, 963-965

161. Rude, R. K., Adams, J. S., Ryzen, E., Endres, D. B., Niimi, H., Horst, R. L., Haddad Jr, J. G.,Singer, F. R. (1985) Low serum concentrations of 1, 25-dihydroxyvitamin D in human magnesium deficiency. J Clin Endocrinol Metab 61, 933-940

162. Sahota, O., Mundey, M., San, P., Godber, I.,Hosking, D. (2006) Vitamin D insufficiency and the blunted PTH response in established osteoporosis: the role of magnesium deficiency. Osteoporos Int 17, 1013-1021

163. Gandhe, M. B., Jain, K.,Gandhe, S. M. (2013) Evaluation of 25 (OH) Vitamin D3 with Reference to Magnesium Status and Insulin Resistance in T2DM. J Clin Diagn Res 7, 2438 
164. Al-Daghri, N. M., Alkharfy, K. M., Khan, N., Alfawaz, H. A., Al-Ajlan, A. S., Yakout, S. M.,Alokail, M. S. (2014) Vitamin D Supplementation and Serum Levels of Magne-sium and Selenium in Type 2 Diabetes Mellitus Patients: Gender Dimorphic Changes. Int J Vitam Nutr Res 84, 27-34

165. Deng, X., Song, Y., Manson, J. E., Signorello, L. B., Zhang, S. M., Shrubsole, M. J., Ness, R. M., Seidner, D. L.,Dai, Q. (2013) Magnesium, vitamin D status and mortality: results from US National Health and Nutrition Examination Survey (NHANES) 2001 to 2006 and NHANES III. BMC medicine 11, 187

166. Farhanghi, M. A., Mahboob, S.,Ostadrahimi, A. (2009) Obesity induced magnesium deficiency can be treated by vitamin D supplementation. J Pak Med Assoc 59, 258-261 167. Huang, J. H., Lu, Y. F., Cheng, F. C., Lee, J. N.,Tsai, L. C. (2012) Correlation of magnesium intake with metabolic parameters, depression and physical activity in elderly type 2 diabetes patients: a cross-sectional study. Nutr J 11, 41

168. Mccarty, M. F. (2005) Magnesium may mediate the favorable impact of whole grains on insulin sensitivity by acting as a mild calcium antagonist. Med Hypotheses 64, 619-627

169. Song, Y., Manson, J. E., Buring, J. E.,Liu, S. (2004) Dietary magnesium intake in relation to plasma insulin levels and risk of type 2 diabetes in women. Diabetes care 27, 5965

170. Kandeel, F. R., Balon, E., Scott, S.,Nadler, J. L. (1996) Magnesium deficiency and glucose metabolism in rat adipocytes. Metabolism 45, 838-843

171. Guerrero-Romero, F., Tamez-Perez, H., Gonzalez-Gonzalez, G., Salinas-Martinez, A., Montes-Villarreal, J., Trevino-Ortiz, J.,Rodriguez-Moran, M. (2004) Oral magnesium supplementation improves insulin sensitivity in non-diabetic subjects with insulin resistance. A double-blind placebo-controlled randomized trial. Diabetes Metab 30, 253-258

172. Takaya, J., Higashino, H.,Kobayashi, Y. (2004) Intracellular magnesium and insulin resistance. Magnes Res 17, 126-136

173. Touyz, R. (2003) Role of magnesium in the pathogenesis of hypertension. Mol Aspects Med 24, 107-136

174. Kazue, I., Terakazu, K.,Motoomi, N. (1997) The effects of nigh oral magnesium supplementation on blood pressure, serum lipids and related variables in apparently healthy Japanesse subjects. Br. J. Nutr 78, 737-750

175. Drenick, E. (1961) The influence of ingestion of calcium and other soap-forming substances on fecal fat. Gastroenterology 41, 242-244 
Table 1: Metabolic syndrome definitions

\begin{tabular}{|c|c|c|c|c|}
\hline & WHO (1999) & EGIR (1999) & NCEP ATP III & IDF \\
\hline Definitions & $\begin{array}{l}\text { insulin resistance } \\
\text { together with two or more } \\
\text { of the following: }\end{array}$ & $\begin{array}{l}\text { Insulin resistance or } \\
\text { impaired } \\
\text { fasting glucose (IFG) } \\
\text { plus two of the following: }\end{array}$ & $\begin{array}{l}\text { Three or more of the } \\
\text { following five risk } \\
\text { factors: }\end{array}$ & $\begin{array}{l}\text { Central obesity plus } 2 \\
\text { other features }\end{array}$ \\
\hline $\begin{array}{l}\text { Fasting plasma } \\
\text { glucose }\end{array}$ & - & $\begin{array}{l}\geq 6.1 \mathrm{mmol} / 1(110 \mathrm{mg} / \mathrm{dl}) \\
\text { but } \\
\text { non-diabetic }\end{array}$ & $\begin{array}{l}\geq 5.6 \mathrm{mmol} / 1(100 \mathrm{mg} / \\
\mathrm{dl})\end{array}$ & $\begin{array}{l}\geq 5.6 \mathrm{mmol} / 1(100 \mathrm{mg} / \\
\mathrm{dl}) \\
\text { or diagnosed type } 2 \\
\text { diabetes }\end{array}$ \\
\hline Central obesity & $\begin{array}{l}\text { Men: waist-hip ratio > } \\
0.90 \\
\text { Women: waist-hip ratio > } \\
0.85 \\
\text { and } / \text { or } \mathrm{BMI}>30 \mathrm{~kg} / \mathrm{m} 2\end{array}$ & $\begin{array}{l}\text { Men: waist circumference } \geq \\
94 \mathrm{~cm} \\
\text { Women: waist } \\
\text { circumference } \\
\geq 80 \mathrm{~cm}\end{array}$ & $\begin{array}{l}\text { Men: waist } \\
\text { circumference }>102 \\
\mathrm{~cm} \\
\text { Women: waist } \\
\text { circumference }>88 \mathrm{~cm}\end{array}$ & $\begin{array}{l}\text { Men: waist } \\
\text { circumference } \geq 94 \mathrm{~cm}, \\
\text { Women: waist } \\
\text { circumference } \geq 80 \mathrm{~cm}^{*} \\
\text { or } \text { BMI }>30 \mathrm{~kg} / \mathrm{m}^{2}\end{array}$ \\
\hline Blood pressure & $\geq 140 / 90 \mathrm{mmHg}$ & $\begin{array}{l}\geq 140 / 90 \mathrm{mmHg} \text { or } \\
\text { treatment }\end{array}$ & $\geq 130 / 85 \mathrm{mmHg}$ & $\begin{array}{l}\geq 130 / 85 \mathrm{mmHg} \\
\text { or treatment }\end{array}$ \\
\hline Triglycerides & $\geq 1.7 \mathrm{mmol} / 1(150 \mathrm{mg} / \mathrm{dl})$ & $>2.0 \mathrm{mmol} / \mathrm{l}(178 \mathrm{mg} / \mathrm{dl})$ & $\begin{array}{l}\geq 1.7 \mathrm{mmol} / \mathrm{l}(150 \mathrm{mg} / \\
\mathrm{dl}) \text { or treatment }\end{array}$ & $\begin{array}{l}\geq 1.7 \mathrm{mmol} / 1(150 \mathrm{mg} / \\
\mathrm{dl}) \text { or treatment }\end{array}$ \\
\hline HDL-cholesterol & $\begin{array}{l}\text { Men: }<0.9 \mathrm{mmol} / \mathrm{l}(35 \\
\mathrm{mg} / \mathrm{dl}) \\
\text { Women: }<1.0 \mathrm{mmol} / \mathrm{l}(39 \\
\mathrm{mg} / \mathrm{dl})\end{array}$ & $\begin{array}{l}<1.0 \mathrm{mmol} / 1(39 \mathrm{mg} / \mathrm{dl}) \text { or } \\
\text { treatment }\end{array}$ & $\begin{array}{l}\text { Men: }<1.03 \mathrm{mmol} / 1 \\
(40 \mathrm{mg} / \mathrm{dl}) \\
\text { Women: }<1.29 \mathrm{mmol} / 1 \\
(50 \mathrm{mg} / \mathrm{dl})\end{array}$ & $\begin{array}{l}\text { Men: }<1.0 \mathrm{mmol} / 1 \mathrm{l}(39 \\
\mathrm{mg} / \mathrm{dl}) \\
\text { Women: }<1.3 \mathrm{mmol} / 1 \\
(40 \mathrm{mg} / \mathrm{dl}) \\
\text { or treatment }\end{array}$ \\
\hline
\end{tabular}


Table 2: Human Studies mentioned the interaction between vitamin D and other nutrients

\begin{tabular}{|c|c|c|c|}
\hline $\begin{array}{l}\text { Authors (year), } \\
\text { Country }\end{array}$ & $\begin{array}{l}\text { Participant } \\
\text { S }\end{array}$ & $\begin{array}{l}\text { Study } \\
\text { design }\end{array}$ & Results and comments \\
\hline \multicolumn{4}{|l|}{$\begin{array}{l}\text { Vitamin A and } \\
\text { vitamin D }\end{array}$} \\
\hline $\begin{array}{l}\text { Schmutz et al. } \\
\text { 2015, USA }\end{array}$ & $\begin{array}{l}15,998 \\
\text { adults }\end{array}$ & Cohort & $\begin{array}{l}\text { Negative associations between serum vitamin } \mathrm{D} \text { and risk of } \\
\text { dead was reported only among individuals with serum } \\
\text { retinylesters }<7.0 \mu \mathrm{g} / \mathrm{dL} \text {. A possible interaction between } \\
\text { serum vitamin } \mathrm{D} \text { and vitamin A levels is probable. }\end{array}$ \\
\hline $\begin{array}{l}\text { Cheng et al. } \\
\text { 2014, USA }\end{array}$ & $\begin{array}{l}14,254 \\
50-69 \text { years }\end{array}$ & $\begin{array}{l}\text { Case- } \\
\text { Control }\end{array}$ & $\begin{array}{l}\text { Vitamin D supplementation was associated with a lower risk } \\
\text { of total lung cancer among individuals who had vitamin } \\
\text { A intake } \geq 1,500 \mu \mathrm{g} / \text { day. Vitamin A may support vitamin D } \\
\text { in cancer prevention. }\end{array}$ \\
\hline $\begin{array}{l}\text { Johansson et al. } \\
\text { 2001, Sweden }\end{array}$ & $\begin{array}{l}9 \text { healthy } \\
\text { subjects }\end{array}$ & Intervention & $\begin{array}{l}\text { Intake of vitamin D plus retinal weakened the calcium } \\
\text { response to vitamin D. Vitamin A intake antagonizes the } \\
\text { quick intestinal calcium response to vitamin D in man. }\end{array}$ \\
\hline \multicolumn{4}{|l|}{$\begin{array}{l}\text { Zinc and vitamin } \\
\text { D }\end{array}$} \\
\hline $\begin{array}{l}\text { Ekbote et al. } \\
\text { 2015, India }\end{array}$ & 31 children & Intervention & $\begin{array}{l}\text { Adding zinc to calcium and vitamin D supplementation } \\
\text { increased the bone mineral content. Zinc supplementation } \\
\text { particularly in the presence of vitamin D increase bone mass. }\end{array}$ \\
\hline \multicolumn{4}{|l|}{$\begin{array}{l}\text { Magnesium and } \\
\text { vitamin D }\end{array}$} \\
\hline $\begin{array}{l}\text { Gandhe et al. } \\
\text { 2013, India }\end{array}$ & $\begin{array}{l}30 \text { healthy } \\
\text { and } 30 \text { type } \\
2 \text { diabetics }\end{array}$ & $\begin{array}{l}\text { Case- } \\
\text { Control }\end{array}$ & $\begin{array}{l}\text { A positive association between vitamin D and magnesium } \\
\text { levels was detected. Vitamin D has the potential to decrease } \\
\text { insulin resistance and also can affect magnesium status. }\end{array}$ \\
\hline $\begin{array}{l}\text { Al-Daghri et al. } \\
\text { 2014, Saudi } \\
\text { Arabia }\end{array}$ & 126 adult & Intervention & $\begin{array}{l}\text { Magnesium levels significantly increased after the vitamin D } \\
\text { supplementation. Vitamin D supplementation increases the } \\
\text { serum level of magnesium }\end{array}$ \\
\hline $\begin{array}{l}\text { Deng et al. 2013, } \\
\text { USA }\end{array}$ & $\begin{array}{l}12157 \\
\text { adults } \\
\text { NHNES } \\
\text { study }\end{array}$ & $\begin{array}{l}\text { Cross- } \\
\text { sectional } \\
\text { and Cohort }\end{array}$ & $\begin{array}{l}\text { High } \mathrm{Mg} \text { intake was diminished the risk of vitamin } \mathrm{D} \text {. A } \\
\text { possible metabolic interaction between vitamin D and } \\
\text { deficiency magnesium is stated. }\end{array}$ \\
\hline $\begin{array}{l}\text { Farhanghi et al. } \\
\text { 2009, Iran }\end{array}$ & $\begin{array}{l}82 \text { women } \\
(17-50 \\
\text { years })\end{array}$ & Intervention & $\begin{array}{l}\text { Vitamin D supplementation increased } \\
\text { serum Magnesium level in obese individuals. In obese } \\
\text { people vitamin D can modify low serum Magnesium levels }\end{array}$ \\
\hline
\end{tabular}


Figure 1: function of vitamin D and vitamin D in gene expression

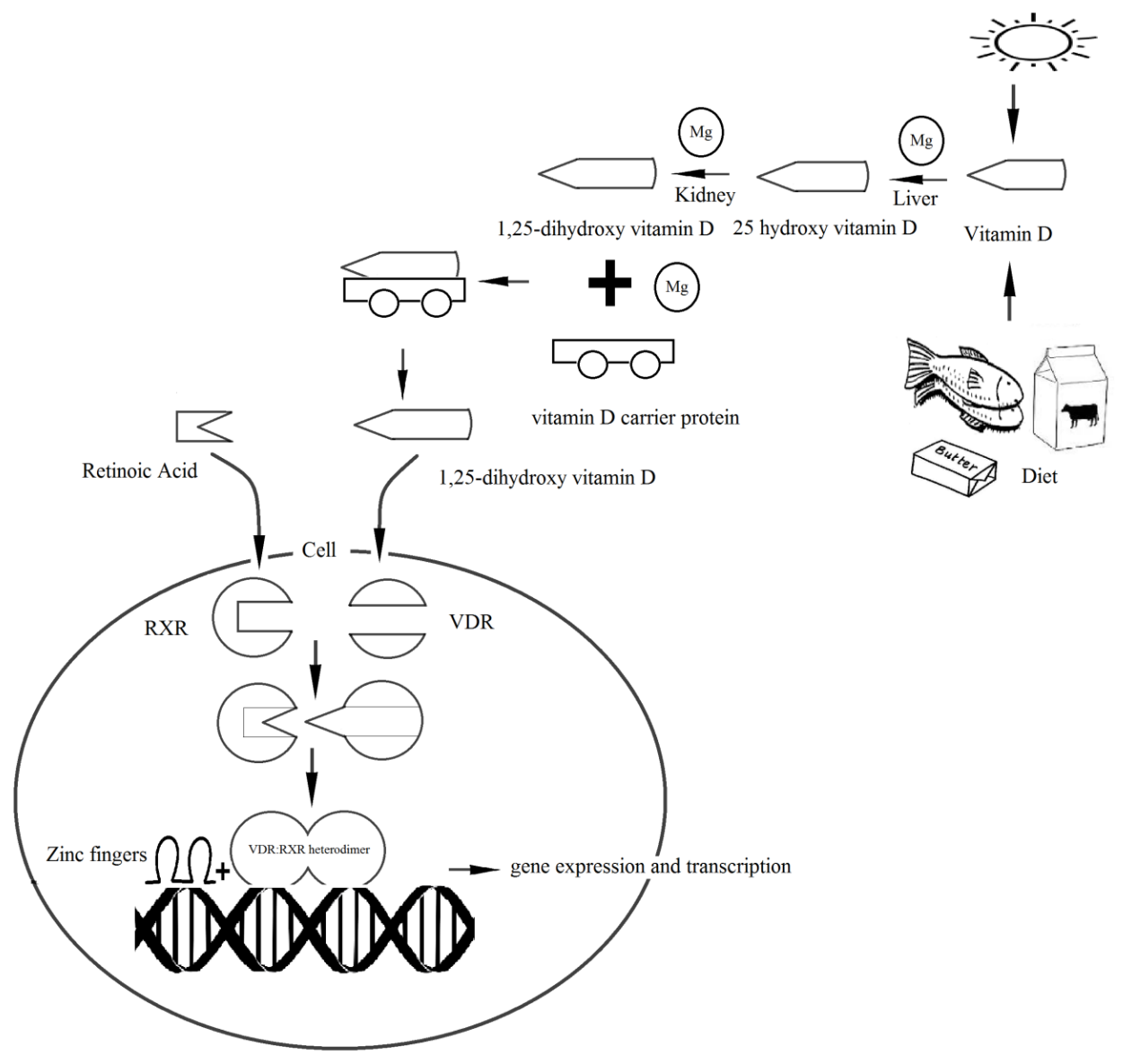

